\title{
Decision-Making Freedom among Households of Lower Income Group in Selangor, Malaysia
}

Norhayah Zulkifli, Abul Bashar Bhuiyan, Tasnuba Haque

To Link this Article: http://dx.doi.org/10.6007/IJARBSS/v11-i11/12035

DOI:10.6007/IJARBSS/v11-i11/12035

Received: 06 September 2021, Revised: 10 October 2021, Accepted: 28 October 2021

Published Online: 18 November 2021

In-Text Citation: (Zulkifli et al., 2021)

To Cite this Article: Zulkifli, N., Bhuiyan, A. B., \& Haque, T. (2021). Decision-Making Freedom among Households of Lower Income Group in Selangor, Malaysia. International Journal of Academic Research in Business and Social Sciences, 11(11), 2633-2649.

\section{Copyright: @ 2021 The Author(s)}

Published by Human Resource Management Academic Research Society (www.hrmars.com)

This article is published under the Creative Commons Attribution (CC BY 4.0) license. Anyone may reproduce, distribute, translate and create derivative works of this article (for both commercial and non0-commercial purposes), subject to full attribution to the original publication and authors. The full terms of this license may be seen at: http://creativecommons.org/licences/by/4.0/legalcode

Vol. 11, No. 11, 2021, Pg. $2633-2649$

Full Terms \& Conditions of access and use can be found at http://hrmars.com/index.php/pages/detail/publication-ethics 


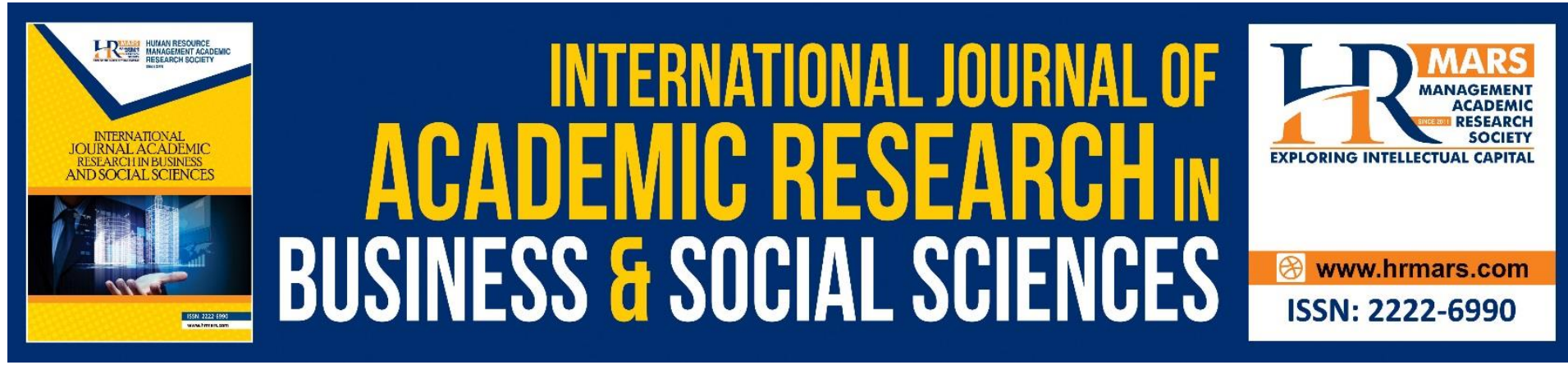

\title{
Decision-Making Freedom among Households of Lower Income Group in Selangor, Malaysia
}

\author{
Dr. Norhayah Zulkifli \\ Professor \& Dean at Faculty of Business and Accountancy (FBA), University Selangor (Unisel), \\ Shah Alam, Malaysia \\ Email: norhayah@unisel.edu.my \\ Dr. Abul Bashar Bhuiyan \\ Associate Professor at Faculty of Business and Accountancy (FBA), University Selangor \\ (Unisel), Shah Alam, Malaysia \\ Email: bashar@unisel.edu.my \\ Dr. Tasnuba Haque \\ Lecturer at Faculty of Business and Accountancy (FBA), University Selangor (Unisel), Shah \\ Alam, Malaysia \\ Email: haquebornee@gmail.com
}

\begin{abstract}
The present study aims to measure the current status of decision-making freedom on economic, social, and household related issues among the lower-income group categorized as the B40 in Selangor, Malaysia. The study utilizes a quantitative approach in analysing the primary data from a sample of 404, B40 people residing in the nine districts of Selangor. A stratified random sampling method is used to select the respondents and descriptive statistics together with Women Empowerment Index (WEI) are utilized in analysing the data. The WEI is employed to measure the status of freedom in terms of economic, social, and household decision-making. The study reveals that there is moderate level of freedom on decisionmaking in all three categories. The present study recommends policy considerations for successful and effective necessary guidelines for decision-making freedom on economic, social, and household related issues among the lower-income group categorized as the B40 in Selangor, Malaysia.
\end{abstract}

Keywords: Women Freedom of Decision-Making, B40 Income Group, Selangor \& Malaysia

\section{Introduction}

The Malaysian government has released its blueprint in the shared prosperity vision 2030 for the period 2021 to 2030 with an aim to increase the income of all ethnic groups particularly the Bumiputeras comprising the B40 in reference to the lower-income group, the hardcore poor, the economically poor, those in economic transition, the indigenous people known as Orang Asli, Sabah and Sarawak Bumiputeras, the disabled, youths, women, children and 
senior citizens (Koya, 2019; Loheswar, 2019). Poverty alleviation, socio-economic wellbeing and sustainable livelihood of the stakeholders are among the prime initiatives of the government (Chua and Oh, 2011; Kronbak and Vestergaard, 2011). It has restructured its past approaches to reduce poverty and inequalities in line with the Sustainable Goal theme 'no one will be left behind'. To become a developed country and sustainbale livelihood, it is very important for Malaysia to alleviate poverty completely and restructure the society. Although the rate of overall poverty in Malaysia has been declining to a negligible percentage, the specific threat from poverty is still noticeable among certain groups, certain areas and states. The government is still facing big challenges to provide enough opportunities on Income Generating Activities (IGAs) towards low income group to achieve certain standards in certain areas. About $40 \%$ of Malaysian households remain in the low income category, earning less than RM1,500 a month, of which $77.2 \%$ are the Bumiputeras. At the same time, the low income group still experiences social inequity, depriving of access to education, healthcare, credit availability, income opportunity, and securing property rights (Courtenay, 1988; Nair, 2001; Sulochana Nair, 2010). This group of people requires specific policy interventions especially on capability development in order to achieve upward mobility. Income disparities between ethnic groups and regions must still be actively addressed.

The current scenario indicates that Malaysia is no longer just grappling with absolute poverty but also with relative poverty, pockets of persistent poverty, the traditional rural poverty, and urban poverty as well as increasing inequalities. A key feature of a green economy is that it seeks to provide diverse opportunities for economic development and poverty alleviation without liquidating or eroding the natural assets of a country (Chua \& Oh, 2011; Kronbak \& Vestergaard, 2011; Nair, 2010). In particular, the ecosystem of goods and services comprise a large component of the livelihoods of the poor rural communities ((Chua \& Oh, 2011; Kronbak \& Vestergaard, 2011; Nair, 2010). During the Tenth Malaysia Plan (10MP 2011-2015), the bottom group consists of 2.4 million households, with $73 \%$ Bumiputeras (locals) and the remaining $27 \%$ are the non-Bumiputeras (non-locals). While in the $11 \mathrm{MP}$ (2016-2020), there were 2.7 million households' monthly income of RM2,537.00, with 68\% Bumiputeras (locals) and $32 \%$ non-Bumiputeras (non-locals); and $56 \%$ in the urban and $44 \%$ in rural areas.

Many studies also concluded that household decision-making freedom is considered as one of the most crucial factors in ensuring smooth income generating among the lower-income group (Ali et al., 2014; Bhuiyan et al., 2013; Bhuiyan \& Hassan, 2013; Bhuiyan et al., 2012; Haque et al., 2018). Therefore, this study takes an initiative to investigate and measure the current status of freedom of decision-making on economic, social, and household related issues among the lower- income group categorized as the B40 in Selangor, the wealthiest state in Malaysia.

Literature Review

Income disparity has become a major economic growth problem faced by most countries globally (Samsudin and Nadzrulizam, 2021). The income gap that exists between the rich and the poor grows wider every year hence, the Malaysian government has set up economic policies and provided various aids that focus on improving the economic situation of the lower-income group of its citizens known as the B40 to reduce the income gap that exist among them. Income inequalities among the B40 households are prominent in Selangor while Kelantan has the lowest maximum and average income value among the B40 from 
all states. The demographic factors that have significant impacts on the distribution of income among the B40 population in Malaysia has been analysed using regression models. Residential area, levels of academic studies and working status of the head of household are the factors that affect the B40 populations in Malaysia (Samsudin \& Nadzrulizam, 2021).

Alshami, Majid, Rashid, \& Adil in 2019 explorative case study conducted semi interviews with 22 poor women in Selangor, Malaysia. They find that the majority of women who received loan three years ago have successfully operated their micro and small enterprises. However, they face huge challenges to sustain the business and the majority of them are still in the infant stage. There are many causes that affect the sustainability of women micro and small enterprises such as lack of product diversity and the inflexibility of the implementation process of loan disbursement and repayment. In the same way, Tammili et al (2018) investigate poverty eradication recipients in Selangor. Descriptive analysis and multiple regression were used to analyze the data and relationship between the dependent variable are measured by income-investment ratio, and independent variables are represented by socio-demographic as well as other related variables. The findings of the study show that most of the respondents were married (95.7 percent) and have secondary education (72.7 percent). In terms of income distribution, most respondents earn less than RM1,500.00. Nevertheless, all respondents show positive income changes after receiving different income generating program schemes from the Amanah Ikhtiar Malaysia (AIM). Multiple regression analysis has identified two variables which are the family workers and hired workers where both significantly influenced the income-investment ratio after joining the income generating program.

Another study by Al-Shami, Majid, Mohamad, and Rashid, in 2017 scrutinize on the women household welfare and empowerment. A cross-sectional survey was employed through the distribution of a questionnaire to 495 women. They observe that income generating initiatives has significant positive effects on borrowers' household income and personal asset acquisition. However, even though the effect of income generating empowers women borrowers in households' decisions-making, it has no effect on women control over minor financials (Al-Shami et al., 2017). On the other hand, Abdelhak et al (2015) investigate the role of institutions in helping farmers deal with their vulnerabilities to poverty. A structured socio-economic questionnaire from a three-round panel survey was undertaken at six-month interval targeting the farmers in Kelantan and Terengganu, Malaysia. Results of the study indicate that institutions are inactive in providing assistance and support to farmers. Often, assistance is provided after an occurrence of a shock. Incidentally, the assistance that is provided does not reach all farmers, partly due to asymmetric information on the availability of the assistance or that farmers are not selected for the assistance. In most occasions, assistance is just not available to the farmers (Abdelhak et al., 2015). In the meantime, they examine the impact of income generating initiatives on women livelihood with main focus on household income in the urban Selangor province. A cross sectional survey was interviewed with 240 of old clients and 100 of new clients, while the stratified random sampling was used to collect the data. The result of multinomial logit suggests that income generating initiatives has positive impact on women household income in urban areas. 


\section{Methodology}

The present study utilizes a quantitative approach in analyzing the primary data from a sample of 404 people categorised as the B40 residing in Selangor. A survey questionnaire was developed to collect data on multidementional deprivation information from the B40 groups. A purposive stratified random sampling method was used to select the respondents based on the nine districts of Selangor comprising Gombak, Klang, Kuala Langat, Kuala Selangor, Petaling, Sabak Bernam, Sepang, Hulu Langat, and Hulu Selangor. The sampling of the present research is based on 17\% of the population which is categorized as the B40 (DOSM, 2019). The selection of sampling for this study is based on 2019 data produced by the Department of Statistic Malaysia (DOSM). The study identifies that there are $17 \%$ of B40 groups in the state of Selangor, 2019, whereas a total of 4,932,695 of population in Selangor are considered as the B40 group. The study considers only 838,558 as total populations that represent the $17 \%$ of the B40 and total suggested sample is 404 . The percentage of population also takes into consideration the races of the population comprising Malay, Chinese, Indians, and others from the eight districts of Selangor.

Descriptive statistics and Women Empowerment Index (WEI) are used in the analysis to measure the household freedom of decision-making in terms of economic, social, and household related issues. Household freedom of decision-making are multi-dimensional as it enables them to realize their full identity and power in all spheres of life. Various studies have been conducted about the issues in measuring freedom of decision-making, but the indicators for measurement are still debatable. Moreover, even the World Bank and other credible agencies have not yet given a rigorous methodology for measuring changes in women empowerment (Malhotra et al., 2002). Nonetheless, this study employs the WEI, which was constructed by (Varghese, 2011). The index of each dimension was constructed, and the minimum and maximum values were chosen for each underlying indicator. The performance in each indicator is expressed as the minimum and maximum value between 1 and 5 in accordance with the construction method of the Human Development Index (UNDP, 2005).

The WEI is then computed as the simple average of the three indexes according to the following formula:

$$
\mathrm{IVij}=\frac{(\mathrm{Xij})-\operatorname{Min}(\mathrm{Xij})}{(\mathrm{Xij})-\operatorname{Max}(\mathrm{Xij})}
$$

where:

$$
\begin{aligned}
& I V i j=\text { index value } \\
& X i j=\text { actual value } \\
& \operatorname{Min}(X i j)=\text { minimum value } \\
& \operatorname{Max}(X i j)=\text { maximum value }
\end{aligned}
$$

The WEI is computed by getting the average of the three indices according to the following formula: $\mathrm{WEI}=1 / 3$ (economic decision-making index) $+1 / 3$ (household decision-making index) $+1 / 3$ (freedom of movement index). Based on the modification of the measurement format, the present study computed household, social, and economic freedom of decision-making and measured the overall values of these three indices. The present study defines the empowerment value of index $0 \%$ as deprived of development and the value $100 \%$ as full freedom of decision-making. A value between $0 \%$ and $50 \%$ is minimum level of freedom of 
decision-making, $60 \%$ to $70 \%$ is medium level of freedom of decision-making, and $80 \%$ or higher is high freedom of decision-making.

\section{Findings}

\section{Gender of Respondents}

Table 1 shows gender of the respondents. It is found that $51.2 \%$ of respondents are male where $48.8 \%$ are female.

Table 1: Gender of Respondents

\begin{tabular}{|l|c|c|}
\hline \multicolumn{3}{|c|}{ Gender } \\
\hline Gender & Frequency & Percent \\
\hline Male & 207 & 51.2 \\
\hline Female & 197 & 48.8 \\
\hline Total & 404 & 100 \\
\hline
\end{tabular}

\section{Location of Respondents}

Table 2 shows the location of the respondents and it is found that $30.90 \%$ of them are living in the rural area while $65.8 \%$ are from Semi-urban, and $3.2 \%$ live in the city areas.

Table 2: Location of Respondents

\begin{tabular}{|l|c|c|}
\hline \multicolumn{3}{|c|}{ Location } \\
\hline Rural & Frequency & Percent \\
\hline Semi-urban & 125 & 30.9 \\
\hline City & 266 & 65.8 \\
\hline Total & 13 & 3.2 \\
\hline
\end{tabular}

\section{Age Range of Respondents}

Table 3 shows that mostly the respondents are in the age range of 41-50 years old comprising $25 \%$ followed by $23.26 \%$ of the $31-40$ years old group, $20.54 \%$ represent the $18-30$ years old group, $51-60$ years-old group at $18.70 \%$, and 65 to 71 or older age group at $13.12 \%$.

Table 3: Age Range of Respondents

\begin{tabular}{|l|c|c|}
\hline \multicolumn{3}{|c|}{ Age Range of Respondents } \\
\hline & Frequency & Percent \\
\hline $18-30$ & 83 & 20.54 \\
\hline $31-40$ & 94 & 23.26 \\
\hline $41-50$ & 101 & 25 \\
\hline $51-60$ & 73 & 18.70 \\
\hline $61-$ Above & 53 & 13.12 \\
\hline Total & 404 & 100 \\
\hline
\end{tabular}

\section{Races of Respondents}

Table 4 shows the race diversity of the respondents comprising Bumiputera Melayu at $58.4 \%$, Chinese at $26.2 \%$, Indians at $14.90 \%$, and $0.5 \%$ of them are from other races. 
Table 4: Races of Respondents

\begin{tabular}{|l|c|c|}
\hline \multicolumn{2}{|c|}{ Races } \\
\hline & Frequency & Percent \\
\hline Melayu & 236 & 58.4 \\
\hline Chinese & 106 & 26.2 \\
\hline Indian & 60 & 14.9 \\
\hline Others & 2 & 0.5 \\
\hline Total & 404 & 100 \\
\hline
\end{tabular}

\section{Employment Status of Households}

Table 5 shows the distribution of the employment status of the respondents. The majority of the respondents are involved with full time employment which is at $48.3 \%$, whereas $17.8 \%$ of the respondents are engaged in self-employment, micro business, small business for income generating activities. However, $5.7 \%$ of them are engaged in the odd worker/informal sector, while part time employment is at $5.2 \%$, and $23 \%$ are them are not working.

Table 5: Employment Status of Respondents

\begin{tabular}{|l|l|l|}
\hline & Employment status & \\
\hline & Frequency & Percent \\
\hline Employed & 195 & 48.3 \\
\hline Part time employed & 21 & 5.2 \\
\hline $\begin{array}{l}\text { Odd worker/Informal } \\
\text { sector }\end{array}$ & 23 & 5.7 \\
\hline $\begin{array}{l}\text { Self-employed/Micro } \\
\text { business/Small business }\end{array}$ & 72 & 17.8 \\
\hline not working & 93 & 23 \\
\hline Total & 404 & 100 \\
\hline
\end{tabular}

\section{Status of Household Head}

Table 6 shows the status of the household head led by family members. The study found that $51 \%$ of them are headed by adult male whereas elderly male-headed comprises $23.3 \%, 10.9 \%$ is led by son, $7.4 \%$ is led by single mother, $3 \%$ is headed by elderly female, $1.7 \%$ by daughter, and $1.2 \%$ by single father.

Table 6: Status of Household Head Led by Family Members

\begin{tabular}{|l|c|c|}
\hline & Household Status & \\
\hline & Frequency & Percent \\
\hline Adult male-headed & 206 & 51 \\
\hline Elderly male-headed & 94 & 23.3 \\
\hline Single father & 5 & 1.2 \\
\hline Son & 44 & 10.9 \\
\hline Adult female-headed & 6 & 1.5 \\
\hline Elderly female-headed & 12 & 3 \\
\hline Single mother & 30 & 7.4 \\
\hline Daughter & 7 & 1.7 \\
\hline Total & 404 & 100 \\
\hline
\end{tabular}




\section{Household Family Structure}

Table 7 shows the distribution of the family structure of the respondents. The findings reveal that $38.4 \%$ of the respondents are married with children under 19 in the family, $37.1 \%$ of them are married with no children under 19 in the family, $10.4 \%$ of them are single and no children, $5.9 \%$ of them are married with no children, $5.2 \%$ of them are single with no children under 19 in the family, and 3\% of them are single with children under 19 in the family.

Table 7: Family Structure of Respondents

\begin{tabular}{|l|c|c|}
\hline \multicolumn{2}{|c|}{ Family Structure of Respondents } \\
\hline Single, no children & Frequency & Percent \\
\hline Single, no children under 19 in family & 42 & 10.4 \\
\hline Single, children under 19 in family & 21 & 5.2 \\
\hline Married, no children & 12 & 3 \\
\hline Married, children under 19 in family & 24 & 5.9 \\
\hline $\begin{array}{l}\text { Married, no children under 19 in } \\
\text { family }\end{array}$ & 155 & 38.4 \\
\hline Total & 150 & 37.1 \\
\hline
\end{tabular}

\section{Household Member Contribution in the Income Structure}

Table 8 shows contribution of the household members in the income structure of the lower income group in Selangor, Malaysia. The study shows that $56.7 \%$ of household income is contributed from paid employment, $39.4 \%$ of income of the household from selfemployment, $19.6 \%$ of income is derived from paid wages of odd jobs, and $3.2 \%$ of income is transfers received from different relatives among the lower income group.

Table 8: Household Member Contribution in the Income Structure

\begin{tabular}{|l|c|c|}
\hline \multicolumn{2}{|c|}{ Source of Household Income } \\
\hline & Frequency & Percent \\
\hline Rent/ASN/ASB/LUTH & 14 & 3.5 \\
\hline Income from self-employment & 159 & 39.4 \\
\hline Income from paid employment & 229 & 56.7 \\
\hline Income from paid wages (Odd jobs) & 79 & 19.6 \\
\hline Transfers received & 13 & 3.2 \\
\hline Other sources & 103 & 25.5 \\
\hline
\end{tabular}

\section{Household Internet Access}

Table 9 shows the distribution of the household internet access among the lower-income group in Selangor, Malaysia. The study found that $48.5 \%$ of the household have paid internet access, and $26.7 \%$ have WIFI access, however, $18.3 \%$ of them do not have the WIFI access in their residents. The study also reveals that $6.4 \%$ of households do not have any internet access in their residents and living area. 
Table 9: Distribution of Household Internet Access

\begin{tabular}{|c|c|c|}
\hline \multicolumn{3}{|l|}{ Internet access } \\
\hline & Frequency & Percent \\
\hline Has Wifi & 108 & 26.7 \\
\hline No Wifi & 74 & 18.3 \\
\hline $\begin{array}{l}\text { Has Internet paid } \\
\text { access at home }\end{array}$ & 196 & 48.5 \\
\hline $\begin{array}{l}\text { No Internet access at } \\
\text { home }\end{array}$ & 26 & 6.4 \\
\hline Total & 404 & 100 \\
\hline
\end{tabular}

\section{Status on Household Freedom of Decision-making}

Table 10 shows the status of the respondent household freedom of decision-making among the lower-income group in the Selangor. The survey data are categorized based on the Observation Scale (Strongly disagree $=1$, Disagree $=2$, No change $=3$, Agree $=4$, and Strongly agree $=5$ ). In terms of decisions about their health care, $85.1 \%$ of the respondents indicated their rights on the decisions about their own health whereas, $4.40 \%$ indicated negative responses. Moreover, the average comment of respondent status recorded from the survey data is 3.96 respectively. Furthermore, $70 \%$ of the respondents indicated that they share on the decision about the health care of their children whereas $12.4 \%$ indicated that they do not have enough freedom. Moreover, the average comment of respondents about the status from the survey data is 3.67 respectively. Moreover, $74.7 \%$ of the respondents indicated their share on the decision with regard to the food to be cooked each day but $10.7 \%$ indicated otherwise. However, the average value of respondent status recorded from the survey data is 3.78. Meanwhile, only $41 \%$ of the respondents indicated their share on the decision on employing servants at home, whereas more than $33.7 \%$ indicated that they do not have the right on this matter. Moreover, the average comment of respondent status recorded from the survey data is 2.93 respectively.

Table 10: Respondent Status on Household freedom of Decision-making

\begin{tabular}{|c|c|c|c|c|c|c|c|c|c|}
\hline \multicolumn{10}{|c|}{ Household freedom of decision-making } \\
\hline \multirow[t]{2}{*}{ Issues } & \multicolumn{5}{|c|}{ Observation Scale } & \multirow{2}{*}{$\begin{array}{l}\text { Average } \\
\text { Value of } \\
\text { Scale }\end{array}$} & \multirow[t]{2}{*}{ SD } & \multirow{2}{*}{$\begin{array}{l}\text { Proportion } \\
\text { of Low } \\
1 \text { and } 2(\%)\end{array}$} & \multirow{2}{*}{$\begin{array}{l}\text { Proportion } \\
\text { of High } \\
4 \text { and } 5(\%)\end{array}$} \\
\hline & 1 & 2 & 3 & 4 & $5 *$ & & & & \\
\hline $\begin{array}{l}\text { Decision about your } \\
\text { health care }\end{array}$ & 9 & 9 & 42 & 272 & 72 & 3.96 & 0.75619 & 4.4 & 85.1 \\
\hline $\begin{array}{l}\text { Decision about } \\
\text { health care of child }\end{array}$ & 19 & 31 & 71 & 226 & 57 & 3.67 & 0.97004 & 12.4 & 70 \\
\hline $\begin{array}{l}\text { Decision about food } \\
\text { to be cooked each } \\
\text { day }\end{array}$ & 14 & 29 & 59 & 230 & 72 & 3.78 & 0.93759 & 10.7 & 74.7 \\
\hline $\begin{array}{l}\text { Decision about } \\
\text { employing servants } \\
\text { at home }\end{array}$ & 82 & 54 & 102 & 142 & 24 & 2.93 & 1.2384 & 33.7 & 41 \\
\hline
\end{tabular}




\section{Status on Freedom of Social Decision-making}

Table 11 shows the status of the respondent household freedom on social decision-making among the lower-income group in the Selangor. The survey data are categorized based on the Observation Scale (Strongly disagree $=1$, Disagree $=2$, No change $=3$, Agree $=4$, and Strongly agree $=5$ ). Most respondents at $76 \%$ indicated their status in terms of making decisions to visit family and relatives, whereas $11.4 \%$ indicated the opposite. The average comment of respondent status recorded from the survey data is 3.75 respectively. In terms of their decisions to visit outside of the village, $72.3 \%$ of the respondents indicated that their status increased, whereas $13.2 \%$ said it decreased. The average comment of respondent status recorded from the survey data is 3.68 respectively. With regard to the decision to go to a health center or hospital on their own, $78.2 \%$ of the respondents indicated their status increased but $8.2 \%$ indicated otherwise. The average value of respondent status recorded from the survey data is 3.8 respectively.

Table 11: Household Freedom of Social Decision-making

\begin{tabular}{|c|c|c|c|c|c|c|c|c|c|}
\hline \multicolumn{10}{|c|}{ Freedom of social decision Indicators } \\
\hline \multirow[t]{2}{*}{ Issues } & \multicolumn{5}{|c|}{ Observation Scale } & \multirow{2}{*}{$\begin{array}{l}\text { Averag } \\
\text { e Value } \\
\text { of Scale }\end{array}$} & \multirow[t]{2}{*}{ SD } & $\begin{array}{l}\text { Proportio } \\
n \text { of Low }\end{array}$ & $\begin{array}{l}\text { Proportio } \\
n \text { of High }\end{array}$ \\
\hline & 1 & 2 & 3 & $\begin{array}{l}1 \text { and } \\
2(\%)\end{array}$ & $\begin{array}{l}4 \text { and } \\
5(\%)\end{array}$ & & & $\begin{array}{l}1 \text { and } 2 \\
(\%)\end{array}$ & $\begin{array}{l}4 \text { and } 5 \\
(\%)\end{array}$ \\
\hline $\begin{array}{l}\text { Decision on } \\
\text { visiting to family } \\
\text { and relatives }\end{array}$ & $\begin{array}{l}1 \\
5\end{array}$ & $\begin{array}{l}3 \\
1\end{array}$ & $\begin{array}{l}5 \\
1\end{array}$ & 247 & 60 & 3.7574 & 0.92 & 11.4 & 76 \\
\hline $\begin{array}{l}\text { Decision on } \\
\text { visiting outside } \\
\text { village/town/cit } \\
\text { y alone }\end{array}$ & $\begin{array}{l}1 \\
4\end{array}$ & $\begin{array}{l}3 \\
9\end{array}$ & $\begin{array}{l}5 \\
9\end{array}$ & 241 & 51 & 3.6832 & 0.93 & 13.2 & 72.3 \\
\hline $\begin{array}{l}\text { Decision to go } \\
\text { to health centre } \\
\text { or hospital } \\
\text { alone }\end{array}$ & $\begin{array}{l}1 \\
3\end{array}$ & $\begin{array}{l}2 \\
0\end{array}$ & $\begin{array}{l}5 \\
5\end{array}$ & 261 & 55 & 3.8 & 0.85 & 8.2 & 78.2 \\
\hline
\end{tabular}

\section{Status on Economic Freedom of Decision-making}

Table 12 shows the status on the economic freedom of decision-making of the respondents' family. The survey data are categorized based on the Observation Scale (Strongly disagree=1, Disagree $=2$, No change $=3$, Agree $=4$, and Strongly agree $=5$ ). With regard to the decisions on how to spend money, $82.2 \%$ of the respondents indicated they have the rights to indulge in the matter, whereas $6.6 \%$ indicated a decrease in their rights. The average comment of respondent status based on the survey data is 3.91 respectively. On decisions about purchasing large household items, such as furniture, $62.9 \%$ of the respondents indicated a high proportion of rights, and $13.3 \%$ of the respondents indicated a low proportion of rights. The average comment of respondent status from the survey data is 3.53. In terms of decisions on buying gifts for social functions, $67.1 \%$ of the respondents indicated that they have the rights however, by contrast, $10.1 \%$ of the respondents indicated otherwise. The average value of respondents' status from the survey data is 3.62 respectively. 
Table 12 Respondent Status on economic freedom of decision-making

\begin{tabular}{|c|c|c|c|c|c|c|c|c|c|}
\hline \multicolumn{10}{|c|}{ Economic freedom of decision-making Indicators } \\
\hline \multirow[t]{2}{*}{ Issues } & \multicolumn{5}{|c|}{ Observation Scale } & \multirow{2}{*}{$\begin{array}{c}\text { Averag } \\
\text { e Value } \\
\text { of } \\
\text { Scale }\end{array}$} & \multirow[t]{2}{*}{ SD } & \multirow{2}{*}{$\begin{array}{l}\text { Proportio } \\
\mathrm{n} \text { of High } \\
4 \text { and } 5 \\
\text { (\%) }\end{array}$} & \multirow{2}{*}{$\begin{array}{c}\text { Proportio } \\
\mathrm{n} \text { of Low } \\
1 \text { and } 2 \\
(\%)\end{array}$} \\
\hline & 1 & 2 & 3 & 4 & 5* & & & & \\
\hline $\begin{array}{l}\text { Decision on } \\
\text { how to spend } \\
\text { money }\end{array}$ & 3 & 24 & 45 & 265 & 67 & 3.91 & 0.75868 & 82.2 & 6.6 \\
\hline $\begin{array}{l}\text { Decision on } \\
\text { purchasing } \\
\text { large } \\
\text { household } \\
\text { items, like } \\
\text { furniture }\end{array}$ & 22 & 32 & 96 & 215 & 39 & 3.53 & 0.96392 & 62.9 & 13.3 \\
\hline $\begin{array}{l}\text { Decision on } \\
\text { buying gifts } \\
\text { for social } \\
\text { functions }\end{array}$ & 19 & 22 & 92 & 229 & 42 & 3.62 & 0.91386 & 67.1 & 10.1 \\
\hline
\end{tabular}

\section{Index Values of Household Decision-making Freedom}

Table 13 and Figure 1 show the level of household freedom of decision-making among the lower-income group in the Selangor. The decision of the lower-income group on their child health care is recorded at $59.85 \%$. Their decision on their health care is about $53.95 \%$, which means that their positions are in the above to medium level of development based on the index values. Moreover, decisions on employing servants at homes are recorded the lowest values at about $56.25 \%$, which denoted that their position was within the medium level of development based on the index values. However, in the case of decision on employing servants at home, it is about $39.00 \%$ which denoted that their position was within the medium level of development based on the index value respectively. Overall, Household Decisionmaking Freedom index values show about $52.26 \%$ improvement among the lower-income group of people. 
Table 13: Household Decision-making Freedom

\begin{tabular}{|l|l|l|l|l|l|}
\hline Particulars & \multicolumn{5}{|c|}{ Household decision-making Freedom } \\
\cline { 2 - 6 } & $\begin{array}{l}\text { Decision on } \\
\text { Your Health } \\
\text { Care }\end{array}$ & $\begin{array}{l}\text { Decision on } \\
\text { Health Care } \\
\text { of Children }\end{array}$ & $\begin{array}{l}\text { Decision on } \\
\text { Food to be } \\
\text { Cooked Each } \\
\text { Day }\end{array}$ & $\begin{array}{l}\text { Decision on } \\
\text { Employing } \\
\text { Servants at } \\
\text { Home }\end{array}$ & $\begin{array}{l}\text { Overall HE } \\
\text { Index Values } \\
(\%)\end{array}$ \\
\hline $\begin{array}{l}\text { Total } \\
\text { Index } \\
\text { Score }\end{array}$ & 299.25 & 269.75 & 281.25 & 195 & 261.3125 \\
\hline $\begin{array}{l}\text { Average } \\
\text { Index } \\
\text { Value }\end{array}$ & 0.5985 & 0.5395 & 0.5625 & 0.39 & 0.522625 \\
\hline $\begin{array}{l}\text { Average } \\
\text { Index } \\
\text { Value \% }\end{array}$ & 59.85 & 53.95 & 56.25 & 39 & 52.2625 \\
\hline
\end{tabular}

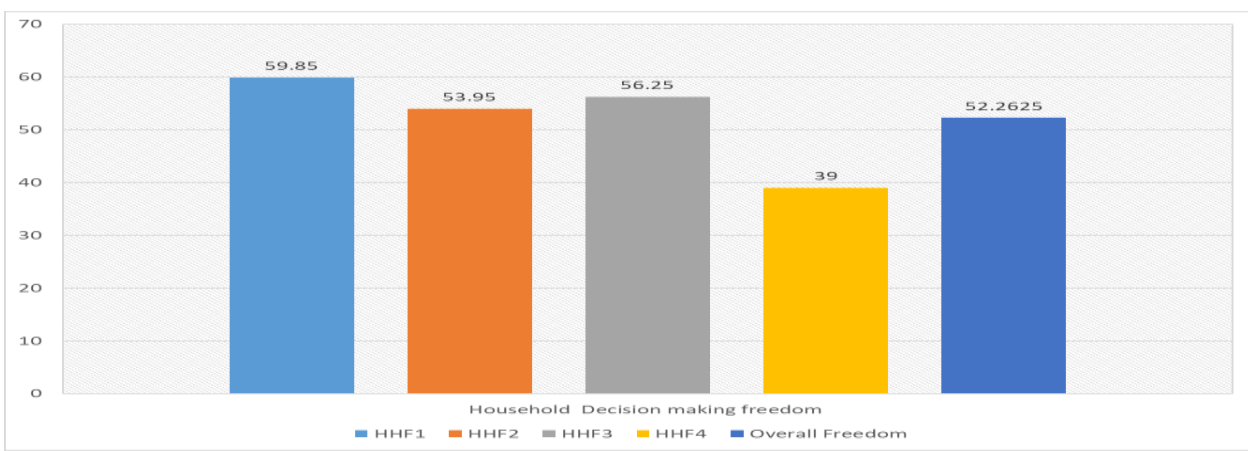

Figure 1 Household Freedom of Decision-making

\section{Social Freedom of Decision-making}

Table 14 and Figure 2 present the social freedom of decision-making of the lower-income group in the Selangor. The decision of the lower income group on visiting their family and relatives is at $55.7 \%$, while their decision to visit outside of their village, town, or city alone is at $54.2 \%$. The findings indicate that their social participations are in the above to medium level of development based on the index values. Moreover, decision to go to health centres or hospitals on their personal capacity recorded the lowest values at $56.65 \%$, which denoted that their position is within the medium level of development based on the index values. 
Table 14: Social Freedom of Decision-making

\begin{tabular}{|l|l|l|l|l|}
\hline Particulars & \multicolumn{4}{|c|}{ Social freedom of decision-making } \\
\cline { 2 - 6 } & $\begin{array}{l}\text { Decision to } \\
\text { Visit Family } \\
\text { and Relatives }\end{array}$ & $\begin{array}{l}\text { Decision to } \\
\text { Visit Outside } \\
\text { the Village, } \\
\text { Town, or City } \\
\text { Alone }\end{array}$ & $\begin{array}{l}\text { Decision to } \\
\text { Go to a } \\
\text { Health } \\
\text { Center or } \\
\text { Hospital } \\
\text { Alone }\end{array}$ & $\begin{array}{l}\text { Overall Social } \\
\text { Empowerment } \\
\text { Index Values \% }\end{array}$ \\
\hline Total Index Value & 278.5 & 271 & 283.25 & 277.58 \\
\hline $\begin{array}{l}\text { Average Index } \\
\text { Value }\end{array}$ & 0.557 & 0.542 & 0.5665 & 0.55 \\
\hline $\begin{array}{l}\text { Average Index } \\
\text { Value (\%) }\end{array}$ & 55.7 & 54.2 & 56.65 & 55.52 \\
\hline
\end{tabular}

Social Decision making freedom

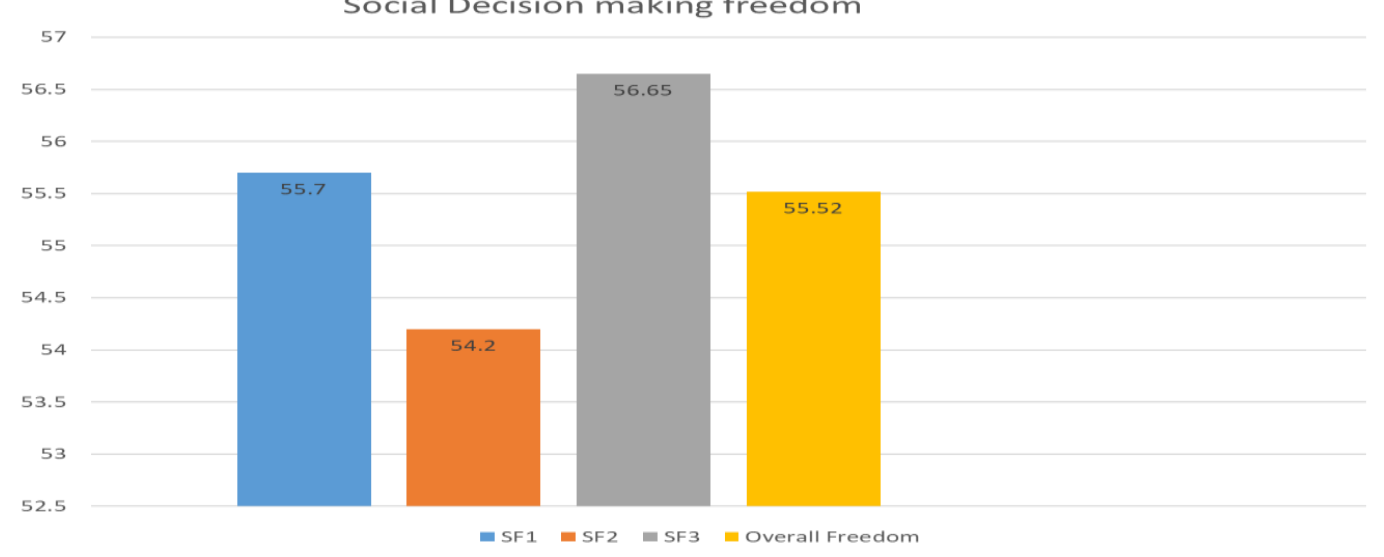

Figure 2: Social Freedom of Decision-making

The overall social empowerment index values show about $55.52 \%$ improvement among the lower-income group in the Selangor. Based on the overall social empowerment index values, the lower-income group improve their rights in social participations.

\section{Economic Freedom of Decision-making}

Table 15 and Figure 3 show the level of economic freedom of decision-making level among the lower income group in the Selangor. Their decision-making power in buying gifts for social functions is at $58.85 \%$, which indicated above medium level of development based on the index values. Moreover, their decision-making power in purchasing large household items, such as furniture, is at $51.25 \%$. With regard to decisions on how to spend money, the lowest value at $53.05 \%$ denote a medium level of development based on the index values. 
Table 15 Economic Freedom of decision-making level

\begin{tabular}{|l|l|l|l|l|}
\hline Particulars & \multicolumn{4}{|c|}{ Economic Freedom of decision-making level } \\
\cline { 2 - 5 } & $\begin{array}{l}\text { Decision on } \\
\text { How to } \\
\text { Spend } \\
\text { Money }\end{array}$ & $\begin{array}{l}\text { Decision on Purchasing } \\
\text { Large Household Items } \\
\text { (e.g., furniture) }\end{array}$ & $\begin{array}{l}\text { Decision on } \\
\text { Buying Gifts } \\
\text { for Social } \\
\text { Functions }\end{array}$ & $\begin{array}{l}\text { Overall EE } \\
\text { Index } \\
\text { Value }\end{array}$ \\
\hline $\begin{array}{l}\text { Total Index } \\
\text { value }\end{array}$ & 294.25 & 256.25 & 265.25 & 271.92 \\
\hline $\begin{array}{l}\text { Average Index } \\
\text { Value }\end{array}$ & 0.5885 & 0.5125 & 0.5305 & 0.54 \\
\hline $\begin{array}{l}\text { Average Index } \\
\text { Value (\%) }\end{array}$ & 58.85 & 51.25 & 53.05 & 54.38 \\
\hline
\end{tabular}

Economic Decision making freedom

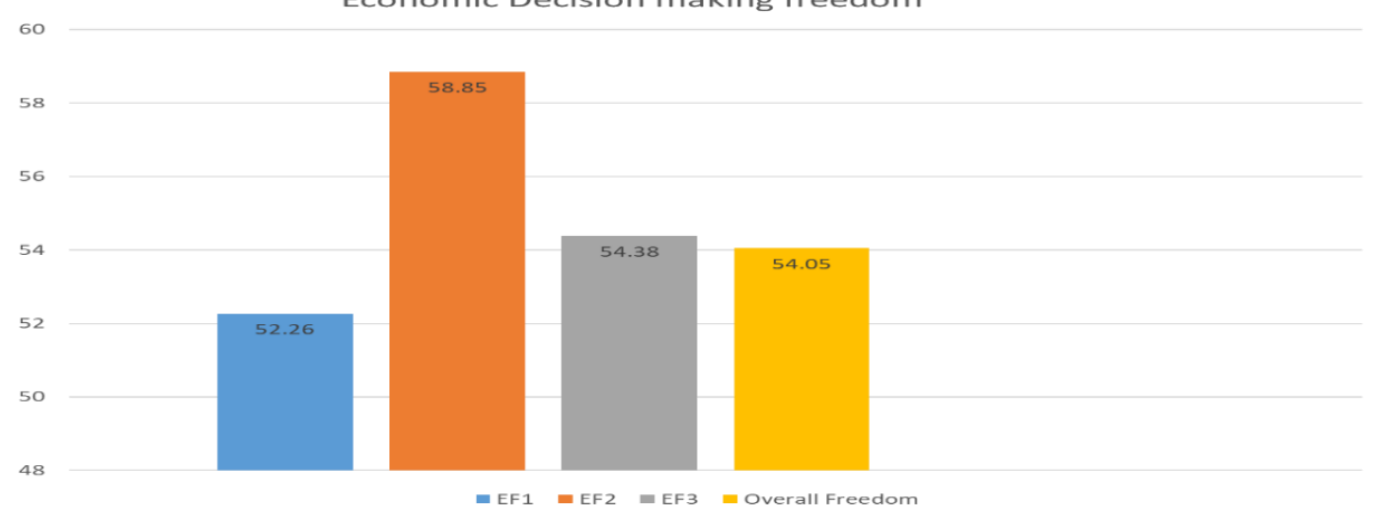

Figure 3 Freedom of Decision-Making Level

The overall economic freedom of respondent scores of index values shows $54.38 \%$ improvement. Based on the overall economic empowerment index values, the lower income group improve their decision-making power regarding economic participation respectively.

\section{Overall Decision-Making Freedom}

Table 16 and Figure 4 show the distribution of overall decision-making freedom of lowerincome group of people in Selangor, Malaysia. The findings reveal that the household decision-making freedom of the lower-income group is recorded at $52.26 \%$. However, $58.85 \%$ of the respondents have freedom of decision-making in the category of the social activities among the B40 family whereas, the average economic freedom of respondent scores of index values is shown at $54.38 \%$ respectively. Finally, the overall freedom of household of decision-making status in the categories of household, social, and economic together is $54.05 \%$ respectively. 
Table 16: Overall Decision-making Freedom

\begin{tabular}{|l|l|l|l|l|}
\hline \multicolumn{5}{|c|}{ Overall Decision-making Freedom of the Lower-Income Group } \\
\hline Item & $\begin{array}{l}\text { Household } \\
\text { freedom }\end{array}$ & $\begin{array}{l}\text { Social } \\
\text { Freedom }\end{array}$ & $\begin{array}{l}\text { Economic } \\
\text { Freedom }\end{array}$ & $\begin{array}{l}\text { Overall } \\
\text { Freedom }\end{array}$ \\
\hline Total Index Value & 261.31 & 294.25 & 271.92 & 270.27 \\
\hline $\begin{array}{l}\text { Average Index } \\
\text { Value }\end{array}$ & 0.52 & 0.5885 & 0.54 & 0.54 \\
\hline $\begin{array}{l}\text { Average Index } \\
\text { Value (\%) }\end{array}$ & 52.26 & 58.85 & 54.38 & 54.05 \\
\hline
\end{tabular}

Overall Decision making freedom Respondents

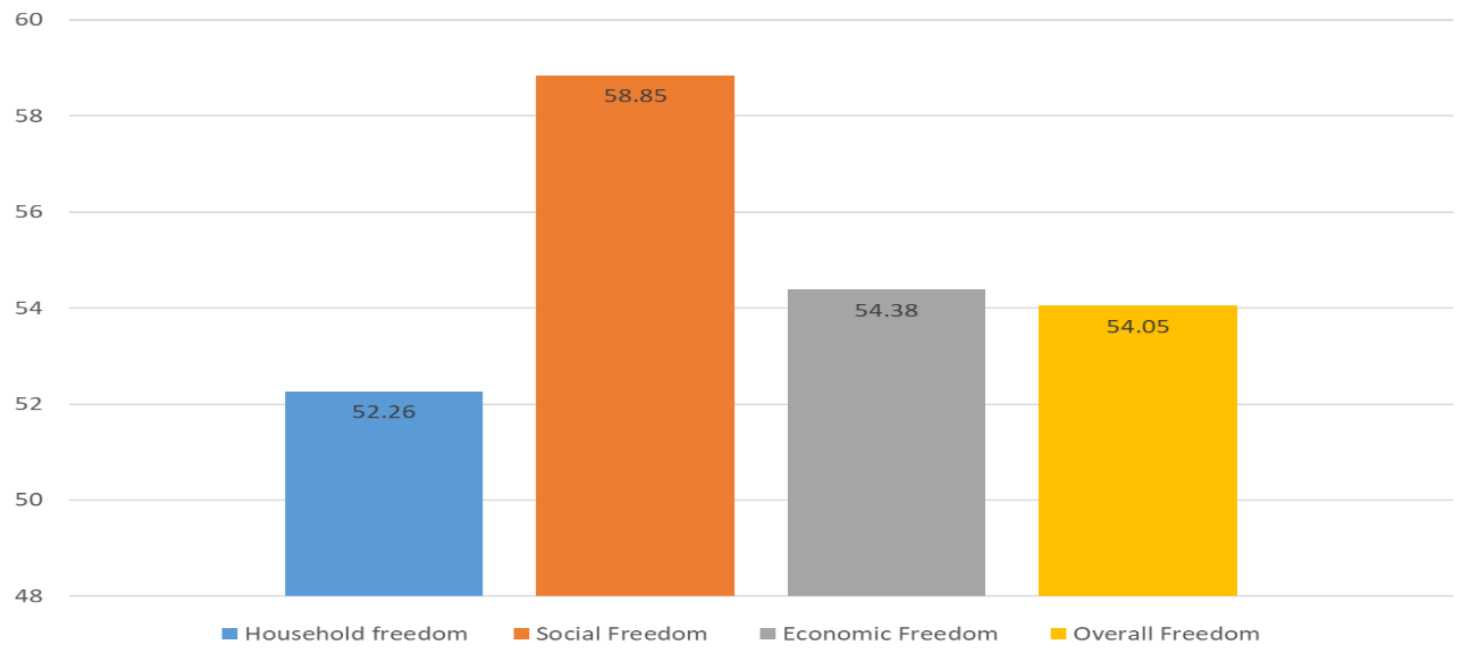

Figure 4: Overall decision-making freedom

\section{Discussion}

The major findings of the study revealed that the status the level of household freedom of decision-making among the lower-income group in the Selangor. The decision of the lowerincome group on their child health care, decisions on employing servants at homes, in the case of a decision on employing servants at home, which denoted that their position was within the medium level of development based on the index value respectively. However, overall, Household Decision-making Freedom is also considered as the medium level of development based on the index values. In the case of the social freedom of decision-making of the lower-income group in the Selangor. Especially for the decision of the lower-income group on visiting their family and relatives, visit outside of their village, town, or city alone and decision to go to health centers or hospitals on their personal capacity are in the above to the medium level of development based on the index values. The overall social freedom of decision-making index values among the lower-income group are in the above to the medium level of development respectively. In the categories of the economic freedom of decisionmaking level among the lower income group in the Selangor. Their decision-making power in buying gifts for social functions, decision-making power in purchasing large household items, such as furniture, decisions on how to spend money are denoting a medium level of development based on the index values. Finally, the overall freedom of household of decisionmaking status in the categories of household, social, and economic together is $54.05 \%$ respectively among the lower-income group in Selangor, Malaysia. 


\section{Conclusion}

The present study investigates the status of household freedom on decision-making among the lower-income group known as the B40 in Selangor, Malaysia. The findings indicate that the majority of respondents are involved with full time employment comprising about $48.3 \%$, whereas $17.8 \%$ of respondents are engaged in self-employment, micro business, and small business for their income generating activities. In the same way, the findings also reveal that $52.2 \%$ of the respondents' main household head are not working and $47.8 \%$ of them are working full time. Besides, the study found that $51 \%$ of them are headed by adult male whereas elderly male-headed comprises $23.3 \%$ of the respondents. Moreover, $56.7 \%$ of the household income is contributed from paid employment, $39.4 \%$ from self-employment, $19.6 \%$ of income derived from paid wages of odd jobs. In the case of monthly household income, it is revealed that $39.1 \%$ of the families have less than RM2,500 of their household monthly income. Overall, the level of decision-making freedom of the lower income group on average is recorded at $52.26 \%$. However, $58.85 \%$ of them are in the of economic freedom of decision-making level. The present study recommends policy considerations for the successful and effective necessary guidelines for the lower income group by increasing income-generating activities, providing sufficient access of credit, and proper education and providing the economic freedom of choice with necessary skill training.

\section{Acknowledgement}

The authors gratefully acknowledged the financial support for this research from the Grant Industry Semesta-2020 Grant No I/SEM-MBI/SS/2020/01

\section{References}

Abdelhak, S., Sulaiman, J., Mohd, S., \& Azman, A. (2015). The Role of Institutions in Alleviating the Vulnerability of Farmers to Poverty in Malaysia: A Longitudinal Study. Kajian Malaysia: Journal of Malaysian Studies, 33, s.

Al-Shami, S. S. A., Majid, I., Mohamad, M. R., \& Rashid, N. (2017). Household welfare and women empowerment through microcredit financing: Evidence from Malaysia microcredit. Journal of Human Behavior in the Social Environment, 27(8), 894-910.

Ali, S., FerdausurRahman, M., Bhuiyan, A. B., \& Sina, A. (2014). Microfinancing impacts on socio-economic development: an empirical study of Grameen Bank in Bangladesh. Advances in Environmental Biology, 554-563.

Bhuiyan, A. B., Chamhuri, S., Ismail, A. G., \& Basri, T. (2013). Microfinance and Poverty Alleviation: A Conceptual Linkage of Microfinancing Approaches for Poverty Alleviation. Journal of Applied Sciences Research." Journal of Applied Sciences Research, 9(1), 17-21.

Bhuiyan, A. B., \& Hassan, A. (2013). Microcredit and sustainable livelihood: an empirical study of Islamic and conventional credit on the development of human capital of the borrowers in Bangladesh. Journal of Economic Cooperation and Development, 34(3), 101-128.

Bhuiyan, A. B., Siwar, C., Islam, R., \& Adhan, K. N. (2012). Greening Economics and Sustainable Livelihood and Socio-economic Well-being of the Low income Households in Malaysia. Research Journal of Environmental Sciences, 6(5), 156-168.

Chua, S. C., \& Oh, T. H. (2011). Green progress and prospect in Malaysia. Renewable and Sustainable Energy Reviews, 15(6), 2850-2861.

Courtenay, P. P. (1988). Rural development and the Fifth Malaysia plan. Journal of Rural Studies, 4(3), 249-261. 
Haque, T., Siwar, C., Ghazali, R., \& Bhuiyan, A. B. (2018). The Microfinance Contributions on the Household Income of the Borrowers of Amanah Ikhtiar Malaysia (AIM) in Malaysia. Selangor Business Review, 3(1), 1-14.

Koya, Z. (2019). Most number of electoral offences in Cameron Highlands, s. The Star, pp. at https://www.malaymail.com/news/malaysia/ 2019/2001/2023/odds-favour-bn-incameronhighlands-by-election-says-umno-youth-chief/1715735 (Accessed April

1715715, 1712019).

Kronbak, L. G., \& Vestergaard, N. (2011). Towards a Green Economy: Pathways to Sustainable Development and Poverty Eradication: Fisheries Investing in natural capital. Retrieved from

Loheswar, R. (2019). Budget 2020: Putrajaya allocates RM671m for sports, youth development. Malay Mail.

Nair, S. (2001). Poverty in Malaysia: A new look at an old problem. Paper presented the Annual Conference of the International Sociological Association Research Committee on "Poverty, Social Welfare and Social Policy RC.

Nair, S. (2010). Moving forward: Its poverty agenda challenges, dilemma and options for Malaysia.

Nair, S. (2010). Moving forward: Its poverty agenda challenges, dilemmas and options for Malaysia. Paper presented at the Proceedings of the Chronic Poverty Research Centre 2010 Conference.

Samsudin, H. B., \& Nadzrulizam, A. A. ( 2021). Relationship between B40 Household Income and Demographic Factors in Malaysia. 